$1-1-1892$

\title{
Potatoe culture, and fertilization, and tests of some varieties of tomatoes
}

D. D. Johnson

Follow this and additional works at: https://researchrepository.wvu.edu/ wv_agricultural_and_forestry_experiment_station_bulletins

\section{Digital Commons Citation}

Johnson, D. D., "Potatoe culture, and fertilization, and tests of some varieties of tomatoes" (1892). West Virginia Agricultural and Forestry Experiment Station Bulletins. 20.

https://researchrepository.wvu.edu/wv_agricultural_and_forestry_experiment_station_bulletins/20 @ WVU. It has been accepted for inclusion in West Virginia Agricultural and Forestry Experiment Station Bulletins by an authorized administrator of The Research Repository @WVU. For more information, please contact ian.harmon@mail.wvu.edu. 
West Virginia University Libraries

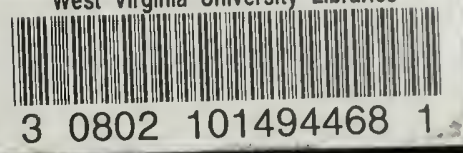





\section{Bulletin No. 20.}

\section{WEST VIEGINIA}

Agricultural Experiment Station MORGANTOWN, W. VA.

POTATOE CULTURE, AND FERTILIZATION, AND

TESTS OF SOME VARIETIES OF TOMATOES. I

EY

D. D. JOHNSON, AGRICULTURIST.

JOHN A. MYERS, PH. D. DIRICTOR.

JANUARY, I892.

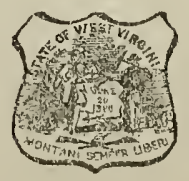

CHARLESTON:

Moezs W. Donzalit, Publio Prantrer 1899. 


\section{BOARD OF REGENTS OF THE WEST VIRGINIA UNIVERSITY,}

\section{Distriot.}

I.

2.

3.

4.

5.

6.

7.

8.

9.

Io.

II.

I2.

13 .
Name of Regent

J. B. SOMMERVILLE, CLARENCE L. SMITH, PEREGRIN HAYES,

JOHN C. VANCE, JOHN G. SCHILLING, EDWARD A. BENNETT, WIET A. FRENCH, M. ). KESTER, j. I. BROWN, THOS. J. FARNSWORTH, JOSEPH. MORELAND, JOHN A. ROBINSON, DR. W. W. BROWN,
ঙ. O. Address.

Wheeling.

Fairmont.

Glenville.

Clarksburg.

Spencer.

Huntington.

Princeton.

Union.

Charleston.

Buckhannon.

Morgantown.

Patterson's Depot.

Kabletown.

\section{MENBERS OF THE STATION COMMITTEE.}

JOHN A. ROBINSON, JOSEPH MORELAND,
JOHN G. SCHILLING, THOS. J. FARNSWORTH, DR. W. W. BROWN.
President of the University,

E. M. TURNER, LL. D.,
TREASURER,

JOHN I. HARVEY.

\section{BTATION STAFF.}

JOHN A. MYERS, PH. D.,

Director. CHAS. F. MILLSPAUGH, M. D., Botanist and Microscopist. A. D. HOPKINS,

D. D. JOHNSON, A. M., Entomologist. RUDOLF DE ROODE, Pr. D., SUSIE V. MAYERS, : . Stencgrapher and Book-keeper. 


\section{POTATOE CULTURE AND FERTIIZATION,}

The primary object of this experiment was to determine the effects f kainit, used alone, and combiner with phosphoric acid and nitroen, as a fertilizer in growing potatoes; and in connection therevith, to test the production of the leading varieties, and the comjarative effects which would be produced by planting the whole poatoe, the halves, the quarters and cut in pieces, each having one :ye; also the effects which would be produced by doubling the imount of seed to a given space.

For this purpose I selected a piece of ground containing 83.6 iquare rods. This land is a yellowish-gray soil and has probably Jeen cultivated for mo:e than fifty years, being so completely "worn out ${ }^{4}$ ' that there was no profit, but an actual loss in its cultivation. This land was "broken up" about the last of March, abou five inches Jeep, horrowed "furrowed-out" and divided into ten plats each, one rod wide and 8.36 rods long, leaving a strip between the plats three feet wide, which was not planted and to which no fertilizers were ap plied. These plats were planted as follows: The rows were 3.83 feet apart, running across all of the ten plats. The first twelve rows were planted with Early Rose; the second twelve with White Star, and the third twelve with Beanty of Hebron. The first three rows of each variety, except White Star, were planted with whole potatoes, three feet apart; the second three rows of all varieties were planted with halves cut lengthwise, eighteen inches apart; the third three rows of each variety with quarters, cut lengthwise, nine inches apart, and the fourth three rows of each variety were planted with pieces containing one eye each, three pieces in a hill, nine inches apart. The first row of the White Star was planted with whole potatoes three feet apart, and the second and third rows were planted with whole potatoes eighteen inches apart, the latter for the purpose of determining the effects of doubling the seed on the same amount of ground. The potatoes were planted on the $13^{\text {th }}$ and the i th days of April, I89r, and "came up" about the ist of May. They were fertilized May 5th by applying one-half of the fertilizer to the rows and by sowing the other half broadcast over the several 
plats, ard the ground rolled immediately thereafter for the purpose of leveling the furrows and pulverizing the clods. There was no rain from the time of planting until the 2oth day of May, but was very seasonable after that time.

Some further explanation is necessary in regard to the character of the soils in the several plats. The quality and condition of the soil in plats I, 2, 3, 4 and 5 sor far as could be determined by careful inspection was practically the same, except that part of No. I planted in White Star, and the first six lows of Beauty of Hebron, and that part of No. 2 in which the last six rows of Beauty of Hebron were planted was of inferior quality. That part of No. 6 on which the Early Rose were planted, and the whole of No. 7 was very poor. No. Io was decidedly the poorest plat of all. The last three rows of the White Star variety un plat No. 9 was probably the best spot in the whole series of plats. Keeping these facts in view, we will be enabled to make a more accurate analysis of the facts presented by this experiment.

The results obtained by the experiment will be treated as follows:

rst. The comparative yield of large and small tubers of the several varieties, produced by the use of different fertilizers.

and. The increased yield produced by the use of different fertilizers, their cost, and profit and loss.

3rd. The comparative yeld of tubers, planted whole, in halves, quarters, and cut to one eye.

4.th. The number and vigor cf the stalks, produced by potatoes planted whole, and cut into halves, quarters, and single eyes.

I. The comparative yield of large and small tubers, of the several varieties, \&c.

Table A. Sets forth in detail, the amount and kind of fertilizers used on each plat and the yield of large and small tubers of each variety. Although the table presents some very interesting facts, we are not prepared to say that it gives any definite data by which we can determine the effects of different fertilizers upon the size of the tubers. Upon this point plats Nos. I, 6 and 10 where Kainit alone was used, seem to contradict each other, while plats Nos. 2 and 7 , also plats Nos. 3 and 8 , substantially agree with each other; yet we may safely infer that the more efficient the fertilizer, the less will be the ratio of small to large tubers. 


\begin{tabular}{|c|c|c|c|}
\hline 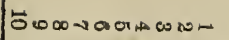 & & Number of Plat. & \\
\hline 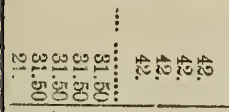 & $\underset{0}{5}$ & Kainit. & 蜀 \\
\hline 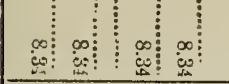 & $\underset{\mathscr{C}}{\vec{E}}$ & Nitratefor Soda. & 舆 \\
\hline 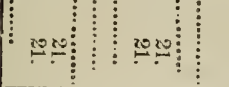 & 5 & $\begin{array}{l}\Delta \text { cid Phosphate (S. C. } \\
\text { Diss. Bone.) }\end{array}$ & 氜 \\
\hline 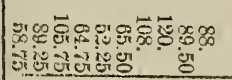 & 5 & Large. & $x$ \\
\hline 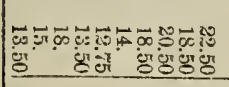 & $\underset{H}{5}$ & Small. & 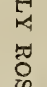 \\
\hline 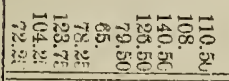 & $\underset{\square}{\square}$ & Total. & \\
\hline 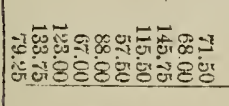 & 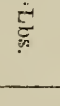 & Large. & 莺 \\
\hline 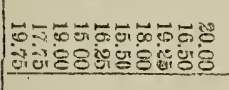 & 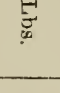 & Small. & 엇 \\
\hline 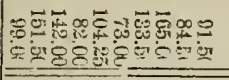 & 5 & Total. & 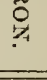 \\
\hline 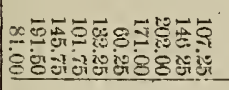 & $\underset{p}{5}$ & Large. & ב \\
\hline 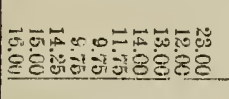 & $\underset{6}{5}$ & Small. & 武 \\
\hline 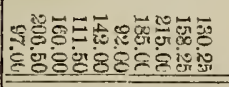 & $\vec{\sigma}$ & Total & \\
\hline 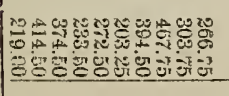 & $\underset{\square}{\breve{E}}$ & Large. & \\
\hline 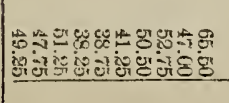 & 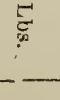 & Small. & $\underbrace{0}_{0}$ \\
\hline 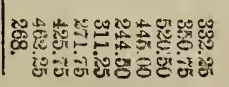 & 耑 & Grand Total. & \\
\hline
\end{tabular}


II. 'The increased yield produced by the use of Commercial Fe: tilizers and the profit and loss in the use of the same.

Table $B$ shows the amourt and cost of the fertilizers applied, th yield, the increased yield produced by the use of fertilizers, th value of the increased yield (estimating the value of the large tubes at fifty cents per bushel and the small dues at 25 cents per bushel and the profit and loss through fertilization, of each variety o each plat; also the totals of the same, together with the increase yield, profit and loss per acre.

Taking the plats from $\mathrm{I}$ to 5 inclusive, we find that No. 5 witt out any fertilization, produced $244 \mathrm{~T} / 2$ pounds of potatoes, while $N$, I, with 42 pounds of kainit, produced $332 \mathrm{~T} / 4$ pounds. The additic of $81 / 3$ pounds of nitrate of soda increased the yield only $18 \mathrm{I} / 2$ pound while thic addition of $2 \mathrm{I}$ pounds of $\mathrm{S}$. C. dissolved bone increase the yield to $520 \mathrm{x} / 2$ pounds, or a net increase over plat No. I wit kainit alone, of $183 \mathrm{x} / 2$ pounds, and a net increase over plat 5 , wi: no fertilizer, of 276 pounds, or more than $\times 13$ per cent. The adc tion of $8 \mathrm{x} / 3$ pounds of nitrate of soda to the amount of fertilizer a plied to No. 3, and applying it to No. 4, actually dıminished t] yield to 445 pounds, or a decrease below No. 3 of $74 \mathrm{x} / 2$ pounds. we compare No. 3 with No. 8 , in which the qualities and conditio of the soil were very nearly the same, we find that by a reduction one-fourth of the amount of kainit, we reduce the yield from 520 to $4253 / 4$ pounds, or a reduction of the increased yield of 94 pounds; in other words, the withholding of $10 \mathrm{x} / 2$ pounds of kain diminished the yield $943 / 4$ pounds. Allowing for the difference the quality and conditions of the soil, plats $6,7,9$ and xo show a proximately the same results, although not in so marked a degr

The profit and loss account is fully set forth in the table a needs no further explanation.

We may safely infer from the results shown by table $B$ :

Ist. That the application of kainit alone at the rate of 800 poun per acre will increase the yield more than 40 per cent.

2nd. That the application of kainit at the rate of 800 poun per acre, and S. C. dissolved bone at the rate of 4.00 pounds $F$ acre, will increase the yield II 5 per cent.

3 rd. That the use of nitrate of soda as a fertilizer for potatc produces no material increase in the crop. 


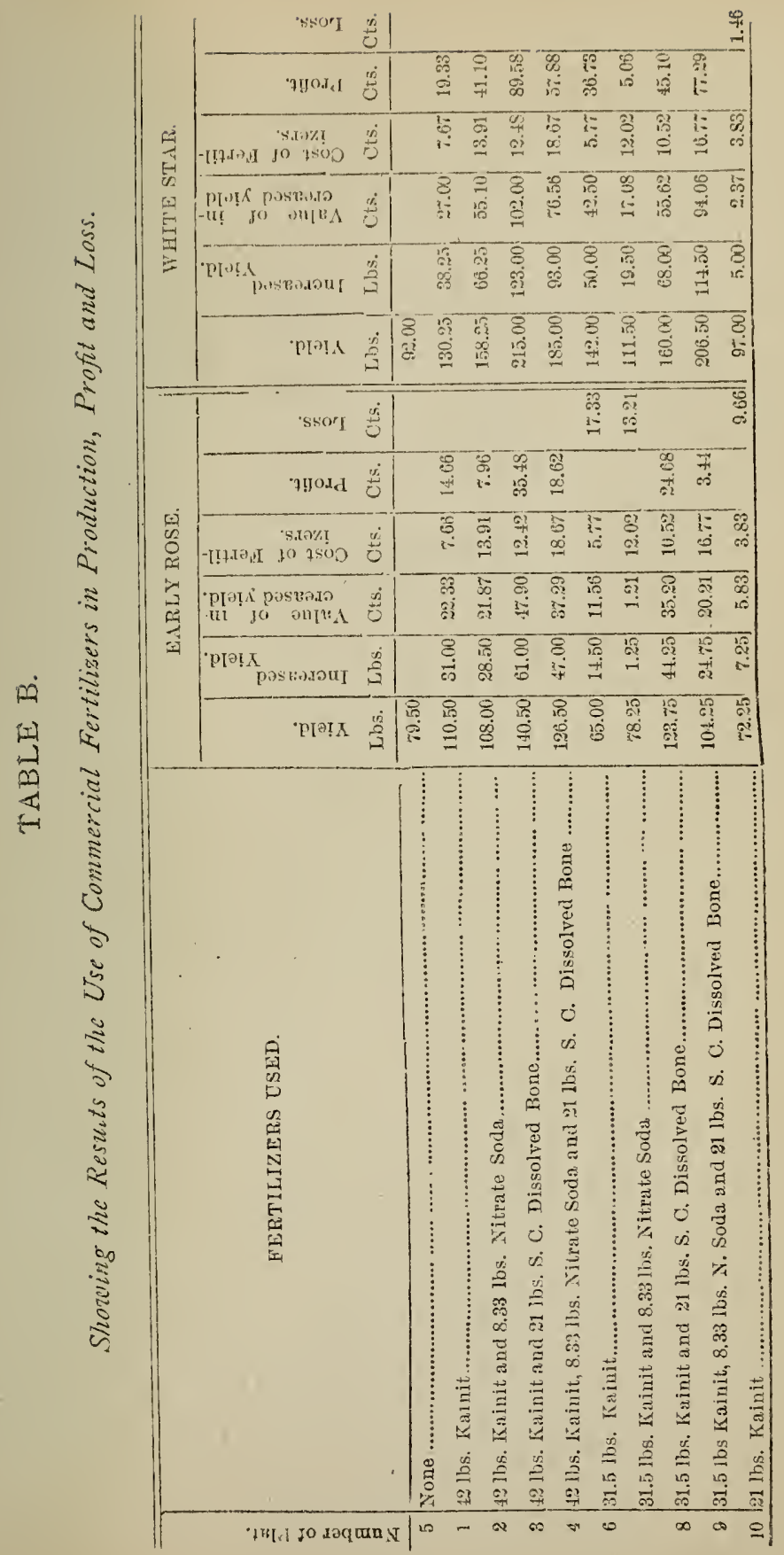


$\times 36$

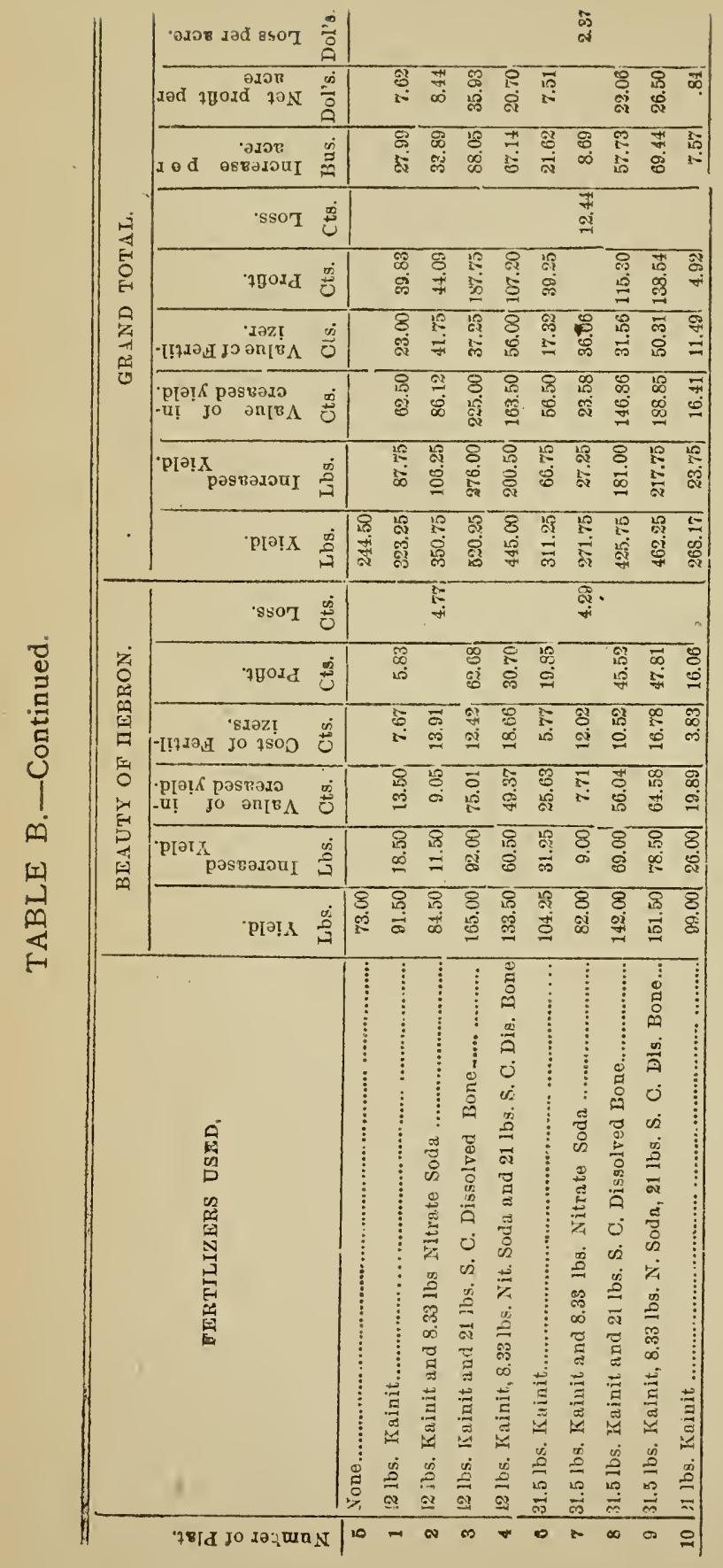



This plate was made from photographs taken by Dr. C. F. Millspaugh, Botanist of this Station. An average hill of the three rows planted with the whole potato of the White Star variety on each of the plats Nos. 3 and 5, were selected and shotographed on the 3 rd day of July. During the month of October, all the potatoes produced in these three rows of plats 3 and 5, were separately and carefully dug, gathered and weighed, and piled in pyramidal form on a table and plotographed. A "tape line," divided into inches, was stretched along the base of the pyramid, so that the size of the tubers, and of the pile, can easily be iscertained. The figures on the right of each pile represent the number of pounds contained therein. The rows in each plat were each one rod long and three and three-tenths feet apart, making the three rows cover three fifths of one square rod. The potatoes produced by the three rows of plat No. 3 weighed $55.8 \mathrm{lbs}$., and the plant and potatoes are represented on the right side of the picture. The potatoes produced by the three rows of plat No. 5, weighed 2 I lbs., and the plant and potatoes are represented on the left side of the picture. To plat No. 5, no fertilizers whatever were applied. To plat No. 3, fertilizers were applied at the rate of $800 \mathrm{lbs}$. of Kainit, and 400 lbs. of S. C. Dissolved Bone per acre. The yield of potatoes for the unfertilized plat was at the rate of eighty-six and two-thirds.bu. per acre, while the yield of the fertilized plat was at the rate of two hundred and forty-eight bu. per acre. The cost of the fertilizers, exclusive of freight, was: Kainit, \$r per ton; S. C. Dissolved Bone, $\$ 3.50$ per tor. The cost per acre as applied in this experiment was $\$ 7.10$. The increased yiald caused by the use of the fertilizers was at the rate of one hundred and sixty-one and one-third bu. per acre, which at $40 \mathrm{cts}$. per bu., amounts to the sum of $\$ 54.53 \frac{1}{3}$, leaving a net profit of $\$ 57.43 \%$ per acre, less the increased labor required to take care of the increased crop.

III. The Comparative Yiald of Large and Small Potatoes, by planting the tubers Whole, in Halves, Quarters, and cut to one eye in each piece.

Table C. shows very clearly the results of cutting the potatoes before planting. It will be observed that in making this test, the ground for each variety on each plat was divided into four equal parts, one-fourth being assigned to Whole potatoes, one-fourth to Halves, one-fourth to Quarters, and one-fourth to pieces containing but a single eye, and to each part was assigned the same number of pounds of seed potatoes, except the first fourth of the White Star variety. This Table should be studied in connection with Table $D$, which shows the number and vigor of stalks produced in each hill. By an examination of this table we find that in the Eariy Rose variety, that the whole potataes, on plats Nos. 7, 9 and ro produced more than the halves, and Nos. $x$ and 2 produced more than the quarters, and No. I produced more than the three eyes (three 
pieces, one eye each, to the hill,) while in all other cases the halves, quarters and single eyes produced decidedly more than the whole potatoes. 'Taking the whole ten plats of the Early Ruse together, we find that the average yield of large potatoes are as follows: Whole, I8.50; Halves, 21.I0; Quarters, 19.90; Three İyes, 24.25; showing that the same amount of seed, planted on the same anount of ground, the whole potatoes produced the smallest amount, while those cut to a single eye in the piece, produced the largest anount, or a little more than 30 per cent. more than the whole potatoe. When we examine the table in regard to the White Star variety, taking into consideration the fact that the amount of seed was doubled (planted 18 inches apart instead of $3 \mathrm{feet}$ ) in the second and third rows of the whole potatoes, the resints are still more remarkable, showing the decided advantage of cutting the potatoe. To show the ratio of increased proluction by an increase of the seed, I increased the seed in the second and third rows 100 per cent., yet the average increase in production is less than so per cent.

The table in the case of the Beauty of Hebron, seems to favor the planting of the whole potatoe, but it is believed that under the same conditions, the same results would appear as in the Early Rose and White Star. Along the upper side of the lot where the Beauty of Hebron was planted, there is an old stony fence row, which could not be properly plorved, and therefore the potatoes planted in it were under very great disadvantage, and failed to mike the growth and production they otherwise would. 


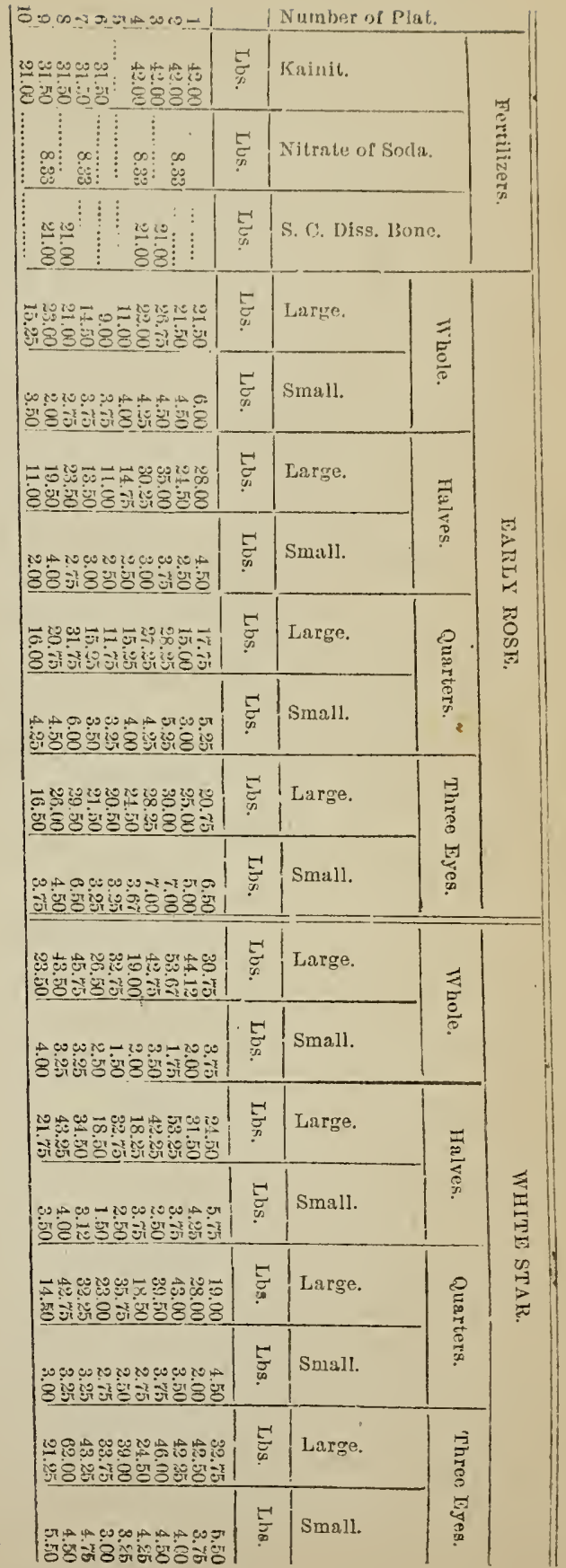


I4I

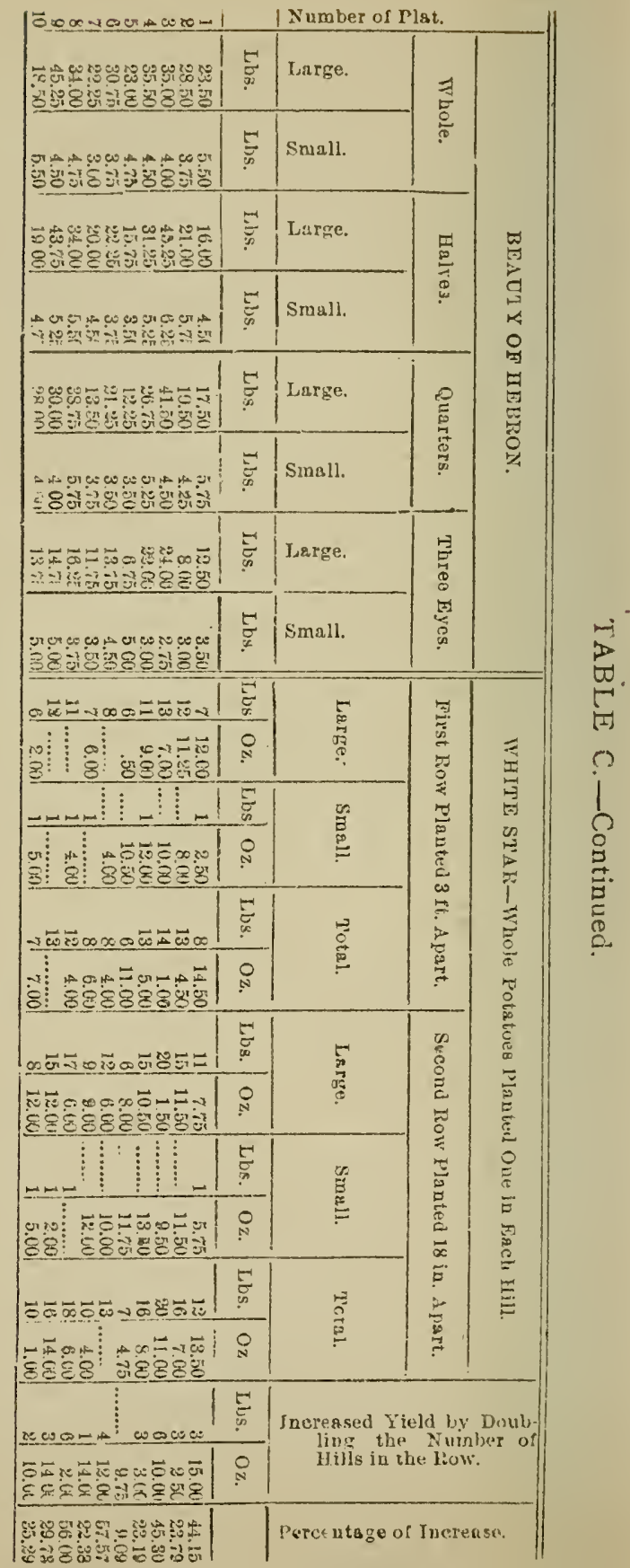


IV. The number and vigor of the Staiks produced by tubers planted whole, and cut into halves, quarters, and single eyes.

By an inspection of Table D., we find that in all varieties, the whole potatoe produces a greaters number and more vigorous stalks, than either the halves, quarters or single eyes, and that the general rule is a gradual diminution of the number and vigor of the stalks, as the size of the pieces planted diminishes, until we reach these cut to one eye in each piece, when we find that the number of the stalks is very materially increased. Estimaring the average number of eyes in each whole potatoe, at $I 6$, we find in the whole potatoe of the Early Rose and Beauty of Hebron, abont one-third, or 33 per cent of the eyes germinate; in the White Star about onefourth, or 25 per cent. Of the halves of the Early Rose and Beauty of Hebron, about 40 per cent., and of the White Star, about 30 per cent. Of the quarters of the Early Rose and Beauty of Hebron, about 60 per cent., and of the White Star, about 50 per cent. Of those cut to single eyes, nearly all germinated. We further find that the increased yield is not in proportion to the increase of the number of staiks. From these facts we infer that in the preparation and planting of the seed to secure the best results, the potatoe should be so cut as to secure one strong vigorous stalk from each piece, and plant so as to secure from three to four stalks to each hill.

The facts set forth in this bulletin are not intended to establish any fixed rules for growing potatoes. They are only intended to show the actual results of the experiment as conducted at this Station, on very inferior soil. Upon other soils and under other conditions the results may be very different; yet it is insisted that the facts herein set forth, are worthy of very careful consideration, and will very materially assist the farmer in preparing his seed for planting, and in selecting the fertilizers necessary to produce the best results. 


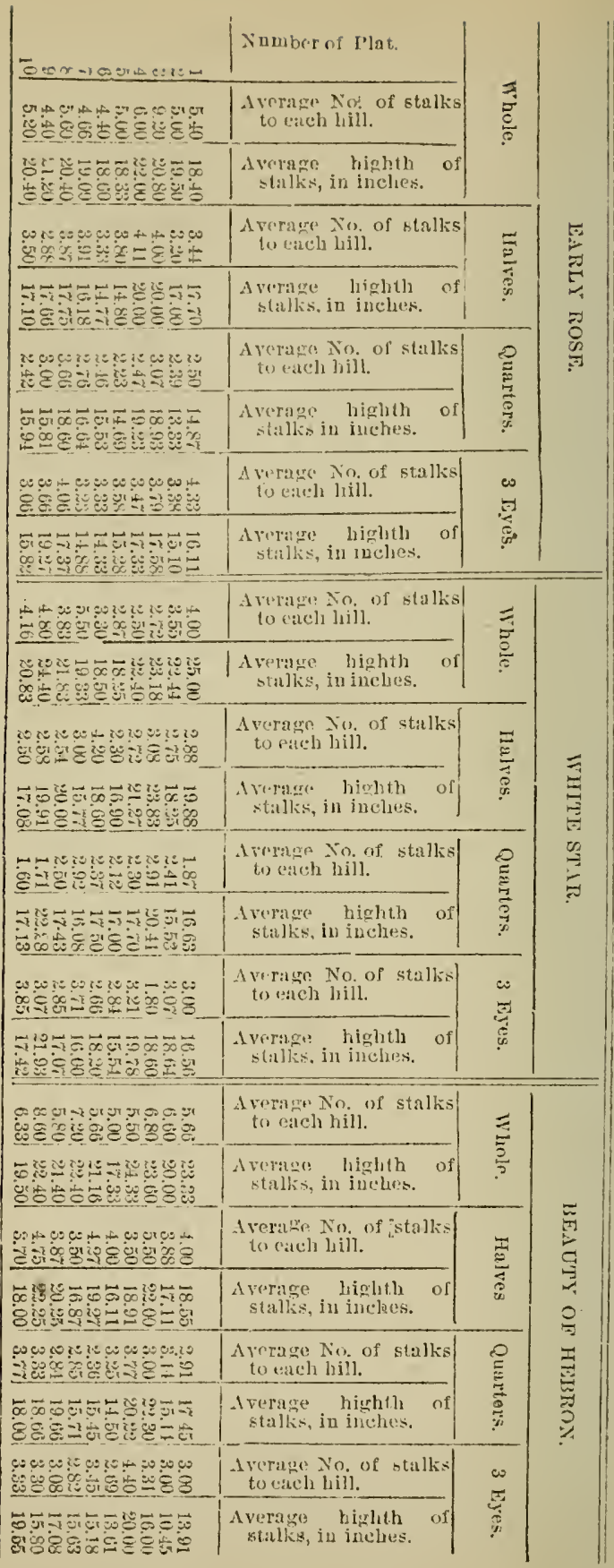




\section{TOMATOES.}

\section{TEST OE VARIETIES.}

The following experiment was conducted for the purpose of testing the comparative merits of some of the leading varieties of tomatoes. The seed was sown in an ordinary hot-ber, aboue the I 5 th day of April, and transplanated to their permanent location about the 20 th day of May. The soil in which they were cultivated, was "brokenup $^{6}$ on the 25 th and 26 th days of March. The soil is a grayish-yellow clay, with no vegetable mould, and had been completely improverished by long cultivation. The tomatoe plants were set in hills three and one-fourth feet apart, in rows five feet apart. The hills were prepared by digging holes seven inches deep and eighteen inches wide, in each of which was put one peck of stable manure, (horse dung). This was thorougly mixed with the clay, by digging down the walls of the hole, leaving the surface of the hill, level with the surface of the ground. After the usual delay caused by transplanting, the plants made a vigorous growth, and by the 25 th day of June, all varieties, except the Mikado, were blooming. On the 3 rd day of July, the Brandywine had attained a heighth of 22 inches, with fruit from one to two inclies in diameter, and plenty of bloom. Early Market Champion had attained a heighth of 20 inches; witn less fruit and bloom than the Brandywine; largest fruit about one inch in diameter. Ignotum had attained a heighth of 20 inches; fruit and bloom a little less plentiful than on Brandywine; largest fruit about one and one-half inches in diameter. Cumberland Red, plants I6 inches high, good set of fruit; largest fruit two inches in diameter. Atlantic Prize, plants 16 inches high, fruit more abundant than on anv other variety; largest fruit about two inches in diameter. 'Mikado, or Turner's Hybrid, 20 inches high, very virgorous growth, no fruit, and very few flowers.

While the plants were yet erect, stakes were driven about eight inches from each plant, to which the plants were tied with common wool twine, to prevent them from falling to the ground. None of the plants were pruned in any manaer. They were cultivated thoroughly, with a horse-cultivator and common hoe, and permitted to grow in the natural way, supported by the stakes as already described. The plants were vigorous and stalky, branching very profusely, and of a dark gieen color. The earliest fruit ripened about the 3 rd day of August, and the first picking occurred on the 5 th. The general ripening of all varieties, except Mikado, did not begin until about the q $_{\text {th }}$ day of August, the first general picking occuring on the I 7 th.

Table E., shows the time of ripening and the amount gathered for each day from the $5^{\text {th }}$ day of August to the $3^{\text {rd }}$ day of October, inclusive. It is somewhat difficult to determine which is the earliest of the four varieties-Brandywine, Early Market Champion, Ignotum and Atlantic Prize. Taking the first three periods of pro- 
duction as shown by Table F., and adding to the first period the amount gathered on the $5 \mathrm{~h}, 6 \mathrm{th}$ and 7 th of August, we have the number of pounds produced by each plant of each variety for the period named, as follows :

\begin{tabular}{|c|c|c|c|c|c|}
\hline . & Brandywine. & $\begin{array}{c}\text { Farly } \\
\text { Market } \\
\text { Champion. }\end{array}$ & Ignotum. & $\begin{array}{c}\text { Allantic } \\
\text { Prize. }\end{array}$ & $\begin{array}{l}\text { Cumberland. } \\
\text { Red. }\end{array}$ \\
\hline 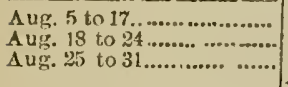 & $\begin{array}{l}0.5 ! \\
0.96 \\
2.06\end{array}$ & $\begin{array}{l}0.40 \\
1.18 \\
206\end{array}$ & $\begin{array}{l}0.64 \\
0.5: \\
2.75\end{array}$ & $\begin{array}{c}0.70 \\
19.3\end{array}$ & $\begin{array}{l}0.31 \\
0.10 \\
3.08\end{array}$ \\
\hline Total ............. & 3.56 & 3.54 & 3.81 & 2.63 & 3.49 \\
\hline
\end{tabular}

For these different periods, we find that in their productiveness, these several varieties rank in the order named, as follows:

First period: Atlantic Prize, Ignotum, Brandywine, Early Market Champion, Cumberland Red.

Second period: Early Market Champion, Brandywine, Ignotum, Cumberland Red, Atlantic Prize.

Third period: Cumberland Red, Ignotum, Brandywine, Early Market Champion, Atlantic Prize.

By reference to Table E., it will be seen that for continuous bearing and productiveness, these varieties have the preference in the order named, as follows: Ignotum, Brandywine, Cumberland Red, Early Market Champion, Atlantic Prize, Mikado or Turner's Hybrid. The Altantic Prize is a very peculiar tomato in several respects. The plant dces not grow large, being much smaller than any of the other varieties named. It has a peculiar habit of "setting" its fruit very abundantly, all at the same time, the plant presenting almost a solid mass of tomatoes from the root to the top. It grows and ripens this setting of fruit, but produces no more. Another serious objection to this tomato is its strong tendency to burst its skin in ripening, leaving its surface thoroughly scarified, and rendering it liably to premature decay during wet weather.

The Mikado, or Turner's Hybrid is a very vigorous grower, the piants being much larger than any of the other varieties tested, but it is nearly three weeks later in setting and ripening its fruit, and ceases bearing about two weeks earlier than the others. Besides, the fruit had a strong tendence to premature decay throughout the season.

The Ignotum, Brandywine, Cumberland Red and Early Market Champion, are worthy of very high commendation, especially the first three named. Their fruit is large and smooth, of a beautiful deep red color, flesh quite solid, good keepers, and specially adapted for market gardens, where shipping qualitics are essential.

During the early part of the ripening sedson of all of these varieties, there is a tendency, of greater or less extent, to premature decay of the fruit. To determine the extent of this tendency, all fruit of this character ripening during the month of August, was separately weighed and the percentage of fruit of each variety 


\section{6}

affected by premature decay was ascertained to be as follows: Brandywine, 10.63 per cent. Early Market Champion, 21.87 perct., Ignotum, I8. I 2 per ct., Cumberland Red, 5.27 per ct, Atlantic Prize, 24.92 per ct., Mikado, or Turner's Hybrid, 20.00 per ct. The quantity of the fruit of the first four varieties affected by premature decay during the month of September, was very small while the fruit of Atlantic Prize and Mikado continued to suffer from premature decay throughout the season. At the time of gathering the last ripe fruit from the Mikado and Atlantic Prize, on the 2 Ist and 2 and days of September, there was no green fruit on the plants; while on the 3 rd day of October, there was an abundance of green fruit on the Brandywine, and a considerable quantity on the Cumberland Red, Ignotum and Early Market Champion, all of which was destroyed by frost. Taking into consideration all of the characteristics of these varieties of tomatoes, I would classify them, in their order of merit, as follows: Brandywine, Ignotum, Cumberland Red, Early Market Champion, Atlantic Prize, Mikado, or Turner's Hybrid. 
TABLE E.

Showing the Date of Ripening and the Yield of Different Varicties of Tonatoes.

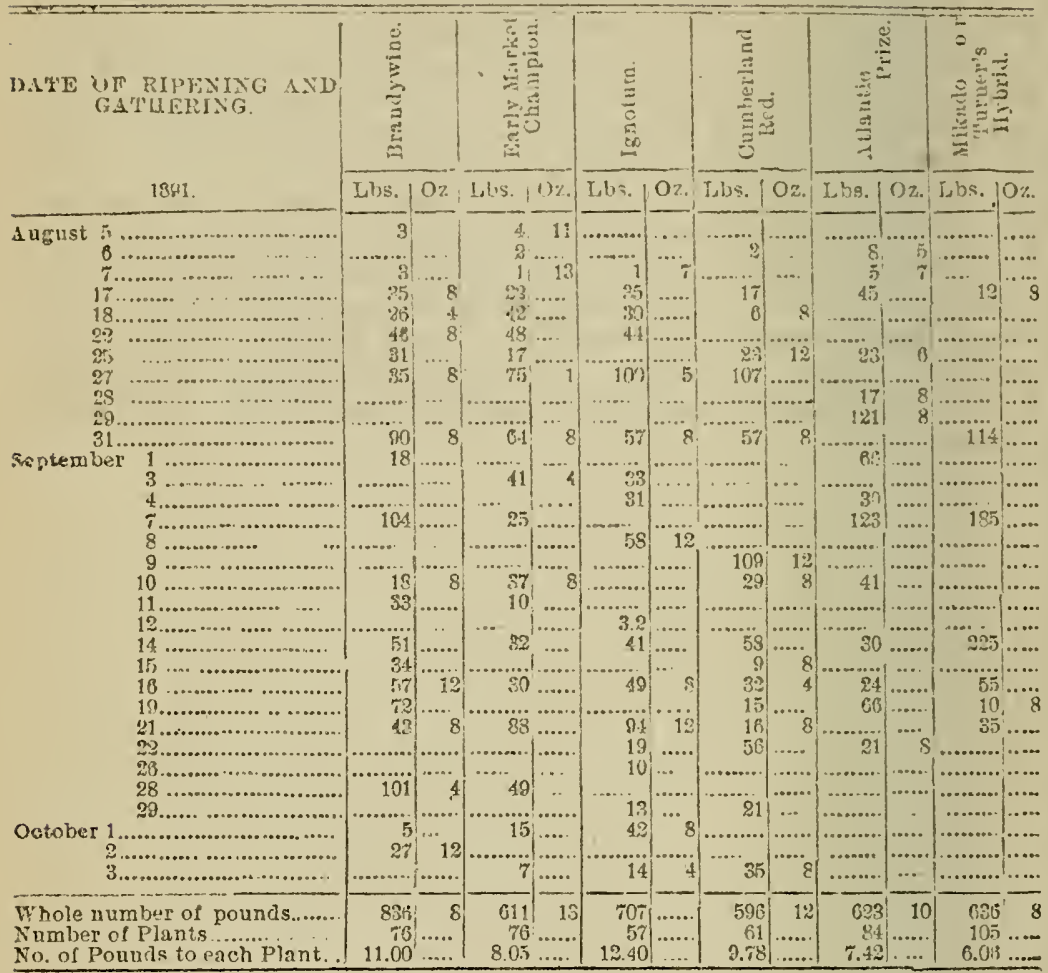




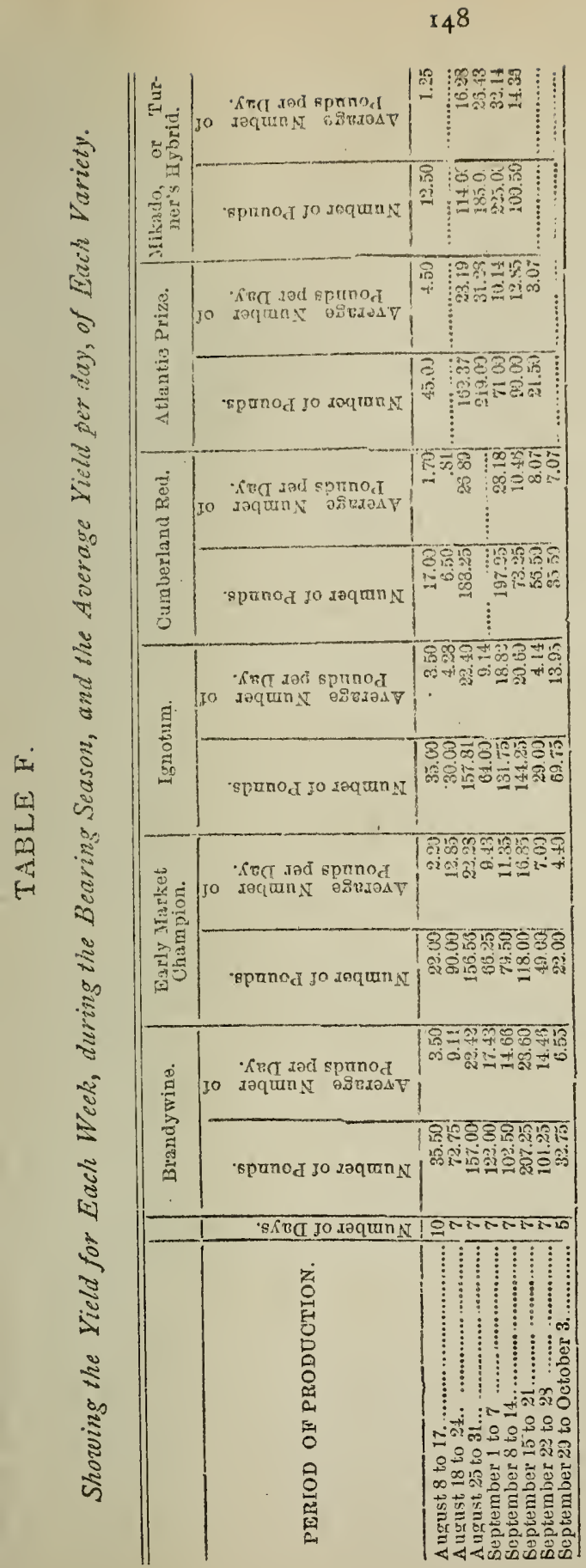


